\title{
A SIMPLE METHOD FOR THE ACCURATE ESTIMATION OF DAILY VARIATIONS IN THE QUALITY AND QUAN- TITY OF HERBAGE CONSUMED BY ROTATIONALLY GRAZED CATTLE AND SHEEP ${ }^{1}$ )
}

\author{
F. K. VAN DER KLEY \\ Publication No. 4, Division of Grassland Husbandry, Agricultural \\ University, Wageningen
}

\begin{abstract}
SUMMARY
A simple cutting method for estimating the daily feed intake by grazing livestock is described. Its usefulness in estimating daily variations in the quantity and quality of herbage consumed by rotationally and strip-grazed livestock is discussed. Formulae for the errors expected in applying the method are derived. Some results obtained with the method, and its practical consequences, are reported.
\end{abstract}

\section{INTRODUCTION}

For estimation of the herbage consumption of grazing cattle and sheep, much attention is being given at present to what are called the indigestible tracer techniques. In these, herbage consumption is calculated from digestibility coefficients, and from the amount of faeces produced, both of which may be estimated from the concentrations of the tracers in samples of the food and faeces. These methods, recently reviewed by vaN DER KLEY (1956a), proved to be useful in determining the amount of herbage ingested during a long period.

\section{THE PROBLEM}

In some experiments, however, we want to know, in particular, the daily fluctuations in the quantity and quality of herbage consumed. Indigestible tracer techniques cannot be applied for this purpose, mainly in consequence of the following fact. The chyme stays for an average of 2-3 days in the reticulo-rumen, where it is mixed continuously with freshly ingested grass. In fact, the indigestible matter occurring in the faeces excreted in one day may be concluded, from BaLch's publications (1950, 1952), to be composed of varying proportions of the feed ingested over the previous period of 7 or more days. Since the amounts of indigestible matter consumed daily may show a similar variation during the grazing period (VAN DER KLEY, 1955), the amount of faeces obviously does not give a reliable indication of the amount of dry matter consumed on any one day.

Daily variations in body weight, recently reviewed by Brown (1954), and possible fluctuations in the amount of faeces produced daily, also make measurements of forage consumption by weighing the animals twice a day (before and after grazing) unreliable.

1) Received for publication October 26, 1955. 


\section{A NEW METHOD}

Holmes, WaIte and co-workers (1952) have shown that estimates of the amounts of consumed grass may be made by measuring the decline in pasture yield during defoliation. In this paper the amounts of grass consumed every day are estimated from the difference $\left(A_{n}-A_{n+1}\right)$; the symbols $A_{n}$ and $A_{n+1}$ represent, respectively, the estimated amounts of dry matter per cow available on the days $(n)$ and $(n+1)$ after fencing-in $(n \geqslant 0)$. These estimates of pasture yield can be made in the normal way by cutting samples. Since the cut herbage has to be removed from the paddock, and since the reliability of the estimates depends on the number of samples rather than on the total area cut (Frankena, 1939, Green, 1949), it is recommended that the total area sampled should be limited, and divided into a large number of sample units, each as small as the cutting technique allows. In order to obtain comparable results it is important that the samples should always be cut to the same level, which should be below the level to which the animals can graze. To achieve this, hand clipping to ground level is probably the most reliable method available at present. In actual fact, such small mowing machines and trimmers as have been developed hitherto do not always cut to the same level, and not always below the level of grazing.

The difference between successive valuations $\left(A_{n}-A_{n+1}\right)$ can be corrected for the growth of the herbage in order to give the amount of dry matter consumed. This can be measured in the normal way, using cages. It should be noted that herbage outside cages grows less rapidly than the protected herbage inside cages; but in fact bias from this source will not be important in intensive grazing systems. This may be seen in Table 1, which shows the average rates of herbage growth inside cages expressed as kilograms of dry matter per cow-day, determined at various stocking rates, under Netherlands conditions.

Table 1 Amounts of grass, grown per cow-day inside cages, at various stocking rates. (Supposed rate of growth : 40-80 kg dry matter per hectare per day).

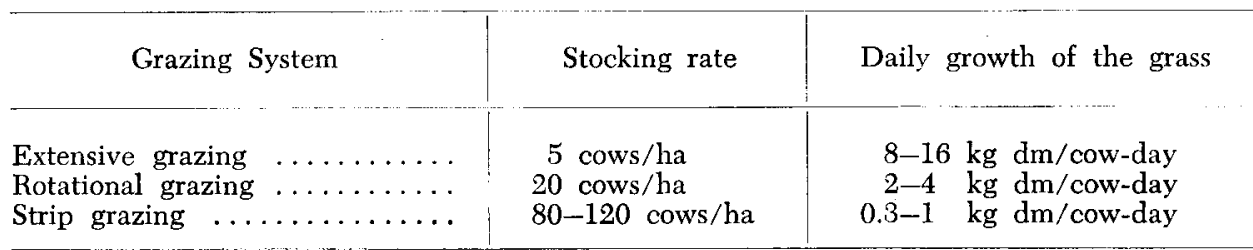

Conversion factors : $1 \mathrm{~kg}=2.205 \mathrm{lbs} ; 1$ ha $=2.471$ acres.

\section{RESTRICTIONS OF THE METHOD}

According to the previous section the quantities of dry matter consumed daily by a single cow have to be calculated as a growth-corrected difference $\left(A_{n}-A_{n+1}\right)$. Its components $A_{n}$ and $A_{n+1}$, defined in that section, may have coefficients of variation of $P_{n}$ and $P_{n+l}$ per cent, respectively. The actual values of $P_{n}$ and $P_{n+1}$ are concluded there to depend mainly on the number of herbage samples and the cutting technique. Errors made in the measurement of herbage growth may be concluded from Table 1 to cause only small deviations in the calculation of quantities of dry matter consumed daily by a rotationally or strip-grazed animal. So the coefficient of variation of dry matter consumed on the $n^{\text {th }}$ day after fencing-in, $v c_{n}$, may be written : 


$$
v c_{n}=\frac{\sqrt{\left(P_{n} \overline{A_{n}}\right)^{2}+\left(P_{n+1} A_{n+1}\right)^{2}}}{A_{n}-A_{n+1}}
$$

In order to get the best estimate of the quantities of herbage consumed, it is recommended that the number of samples should be gradually increased on successive days from the start of the grazing period, thus making $P_{n+1}$ nearly equal to $P_{n}$. If this is carried out, Formula (1) may be simplified further :

$$
v_{n}^{r}=\frac{P_{n} \sqrt{\left(A_{n}\right)^{2}+\left(A_{n+1}\right)^{2}}}{A_{n}-A_{n+1}}
$$

In applying formula (2) to various amounts of dry matter consumed, and to various species of animals, it is more convenient to express the amount of herbage dry matter available in terms of grazing-days per animal. If a stripgrazed or rotationally grazed animal consumes $\left(A_{n}-A_{n+1}\right)=x_{n} \mathrm{~kg} \mathrm{dm}$ on the $n^{\text {th }}$ day from the start of the grazing period, the number $q_{n}$ of grazingdays per animal that might theoretically be expected with effect from the morning of this day is $A_{n} / q_{n}$, if the amount of dm available were to be consumed entirely and if the growth of the herbage during the grazing period were neglected.

Consequently, under practical grazing conditions :

$$
A_{n} \approx q_{n} \cdot x_{n}
$$

Furthermore : $A_{n+1} \approx\left(q_{n}-1\right) x_{n+1}$

To simplify the problem $x_{n}$ and $x_{n+1}$ are supposed to be nearly equal.

After substituting (3) and (4) in Formula (2), and reducing the fraction, we then obtain the formula :

$$
v c_{n}^{l} \approx p_{n} \gamma_{q_{n}}^{2}+\left(q_{n}-1\right)^{2}
$$

This formula can also be written as :

$$
v c_{n}^{1} \approx p_{n} \sqrt{2\left(q_{n}-\frac{1}{2}\right)^{2}+{ }_{2}^{1}}
$$

According to the previous section the herbage should always be cut below the level to which the animal can graze. Consequently $q_{n}$ has to be $\gg 1$. From a grazing trial with dairy cattle carried out by VAN DER KLEY (1955) $q_{n}$ may be concluded to be $\gg 2$. In extensive farming $q_{n}$ may be still higher, owing to the fact that the cow refuses, inter alia, herbage that has been soiled by manure. In fact, in Formula (5a) we may neglect the term $1 / 2$, so that the formula for $v c{ }_{n}^{l}$ may be written as :

$$
v{ }_{n}^{l} \approx 1.41 p_{n} \cdot\left(q_{n}-\frac{1}{2}\right)
$$

The amount of $v c_{n}^{l}$ may be seen from Formula (6) to be positively correlated with $p_{n}$ and $q_{n}$. For accurate estimation of daily herbage consumption, $v c_{n}^{I}$ should not exceed 20 . It can easily be calculated from Formula (5) and (6) that then, in practice, $p_{n}$ and $q_{n}$ should not exceed 5-8 and 7, respectively. This means that accurate estimates of pasture yield are necessary, and that the livestock should go into a fresh paddock at least every 5-10 days. In actual fact, the last-mentioned condition limits the usefulness of the method to rotationally and strip-grazed animals. In more extensive grazing systems estimates might be made of the growth-corrected difference $\left(A_{n}-A_{n+x}\right)$, representing the amount of herbage dry matter consumed by a single cow 
between the $n^{\text {th }}$ and $(n+x)^{\text {th }}$ day from the start of the grazing period $(x \gg 1)$. From Table 1, however, the precision achieved in this way may be concluded to be limited by the growth of the herbage per cow during the grazing period. In fact the method proposed may be useful only at stocking rates higher than about 15 cows per hectare (6 cows per acre), or a corresponding number of other animals.

\section{Quality of CONSUMEd Forage}

Daily variations in chemical composition and nutritive value of the herbage consumed can be estimated in the following way. The percentages of crude protein in the dry matter of the herbage available on the $n^{\text {th }}$ and $(n+1)^{\text {th }}$ day from the start of the grazing period are represented by the symbols $c_{n}$ and $c_{n+1}$, respectively. Consequently, the amounts of crude protein available per cow on these days are $A_{n} c_{n}$ and $A_{n+1} \cdot c_{n+1}$, respectively. The amount of crude protein $\left.{ }^{2}\right)$ consumed can be estimated as $\left(A_{n} \cdot c_{n}-A_{n+1} \cdot c_{n+1}\right)$, which was contained in $\left(A_{n}-A_{n+1}\right) \mathrm{kg}$ dry matter. The best estimate of the percentage of crude protein in the dry matter consumed on the $n^{\text {th }}$ day from the start of the grazing period will then be:

$$
C_{n}=\frac{A_{n} \cdot c_{n}-A_{n+1} \cdot c_{n+1}}{A_{n}-A_{n+1}}
$$

The crude fibre and mineral contents of the herbage consumed on the $n^{\text {th }}$ day after fencing-in can be estimated in the same way. The digestible crude protein content of the herbage consumed may be estimated from its crude protein content, using regression equations given by Dijkstra (1954). By means of similar equations given by him the starch equivalent of the herbage consumed can be estimated from its crude fibre and total ash content.

Formula (7) can also be written as :

$$
C_{n}=c_{n+1}+\left|\frac{A_{n}}{A_{n}-A_{n+1}}\right| \cdot c_{n}-c_{n+l}
$$

hence the precision of the estimate of the quality of the herbage consumed is concluded to be mainly determined by the qualitative correctness of samples and the accuracy of chemical analysis.

\section{AN APPLICATION OF THE METHOD}

The method has been applied in grazing trials with dairy cattle, extensively described in Dutch by VAN DER KLEY (1955, 1956b). In some of these trials (VAN DER KLEY, 1955) the mutual relations between grazing behaviour and quantities and qualities of herbage available and consumed on successive days after fencing-in have been studied. In Table 2, the quality of the herbage consumed during these trials (1955) is compared with the quality of the herbage available before and after grazing. The nutritive value of the herbage consumed is shown to decrease rapidly on successive days of grazing.

2) The symbol $c$ indicates that no correction has been made for the growth of the herbage. 


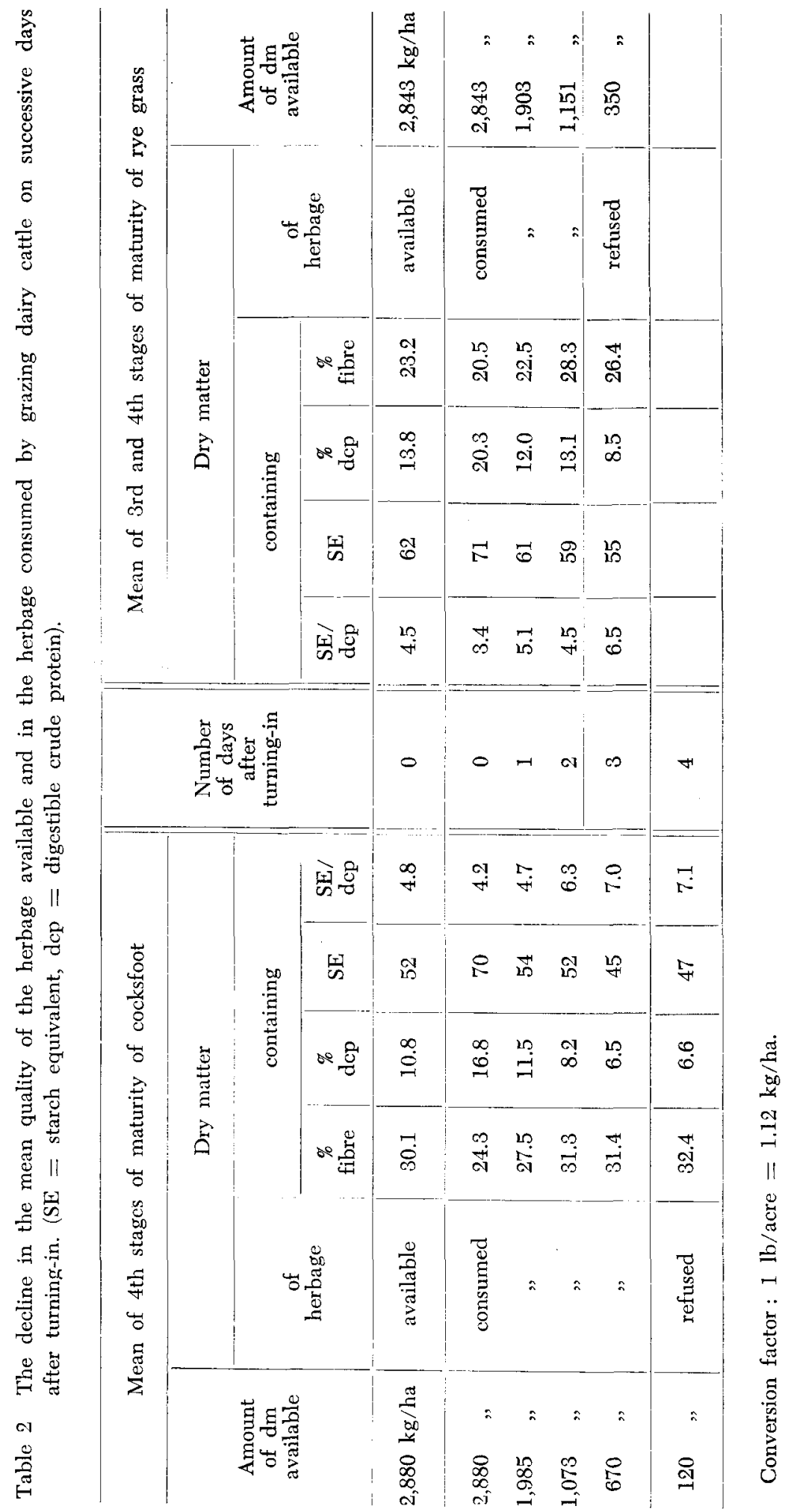


Since the percentage of $\mathrm{dcp}$ in the food decreases more rapidly than the $\mathrm{SE}$, the $\mathrm{SE}: \mathrm{dcp}$ ratio increases in the course of the grazing period. The percentage of crude fibre in the herbage consumed increases proportionately. Nevertheless, the quality of the herbage consumed every day was superior to the mean quality of the herbage available in the morning of these days.

Figure 1 shows that the cows consumed more dry matter when more herbage per hectare and per cow was available. So from Figure 1 it may be concluded that the quantities of dry matter consumed decrease on successive days after fencing-in.

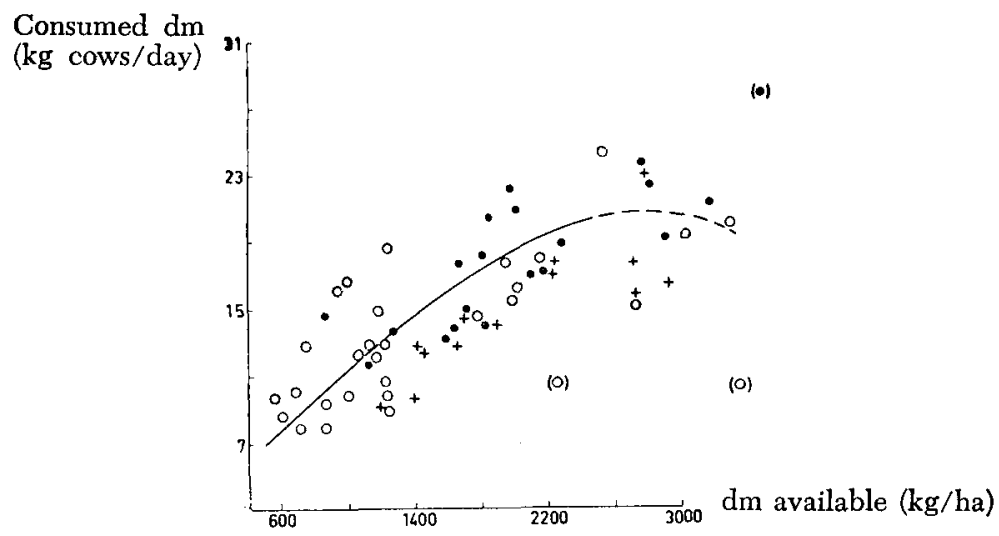

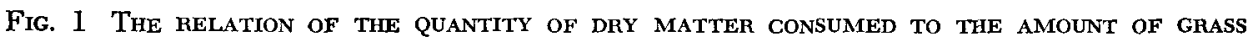
AVAllable, STOCKING RATES BEING 54 COWS PER heCTARE. Black POINTS AND CROSSES HAVE BEEN TAKEN FRoM BosCh (1950), CIRCles from VAN DER KLEY (1955).

$+=$ permanent peaty grassland in spring 1949 .

- " " " , , summer 1949.

$0=$ various leys on sandy soil in summer 1954.

\section{Practical CONSEQuences}

From the above-mentioned the quality of the herbage consumed, as well as its quantity, is concluded to decrease in the course of the grazing period. So the cow is expected to ingest only small amounts of protein towards the end of the grazing period. Immediately after the cow is transferred to fresh pasture, however, the change to food of high protein content will whet its appetite. The excess of protein suddenly ingested after turning-in to fresh pasture may cause scours, and this is often responsible for a decline in the digestibility of the food. Indeed Alexsson (1943) and Merner (1950) have shown that the efficiency of utilization of protein is negatively correlated with the excess in the amounts consumed. Although starch equivalten in excess may be retained in the form of fat, as a reserve of energy for the production of milk in the future, the efficiency of energy utilization for milk production will be $40 \%$ less than the efficiency obtained in the direct transformation of grass into milk by the cow.

From this it may be concluded that excessive feed consumption immediately after the cow enters a fresh paddock can be responsible for considerable waste of protein and energy. This conclusion is illustrated in Figure 2, which shows a rapid decline in consumption of nutrients by rotationally grazed dairy cattle on successive days after fencing-in. 
Feed intake and production

(official indoor standard $=100 \%$ )

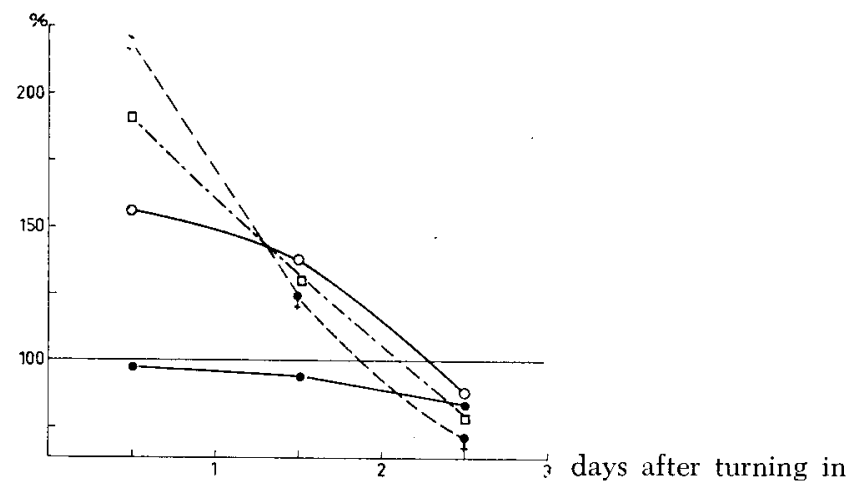

Fig. 2 Mean feed intake (8 paddocks) and $3.33 \%$ FCM production by eight rotatuonally GRAZED DUTCH COWS (VAN DER KLEY, 1955).

-.----- = digestible crude protein (dcp).

..... ם..... = starch equivalent (SE).

$-0 \ldots . .=$ dry matter $(\mathrm{dm})$.

- $=3.33 \%$ Fat Corrected Milk (FCM).

It should be noted that the waste of dep and SE cannot be computed quantitatively from Figure 2 owing to the short experimental periods and the use of indoor feeding standards. Nevertheless, the disadvantage of the gradient shown in Figure 2 may be stressed.

In practice, during rotational or free grazing, milk production usually declines before the available herbage has been completely consumed. If the farmer is able to transfer the restless herd to a fresh paddock when this occurs, he will do so. The animals will then have consumed, on average, during the whole grazing period more nutrients than they required, according to theoretical feeding standards. This excessive feed intake, and these periodical variations in its quality, can best be prevented by close-folding the cattle on herbage not exceeding $17 \mathrm{~cm}\left(7^{\prime \prime}\right)$ in height. In the Netherlands this height usually corresponds to about $1800 \mathrm{~kg}$ of dry matter per hectare $(2,000 \mathrm{lbs} / \mathrm{acre})$.

\section{ACKNOWLEDGMENTS}

The author is grateful to the Director of the Institute for Research on Varieties of Field Crops (I.V.R.O.), and to his collaborator Mr. H. Vos M. Sc. (Agr.) for giving him the opportunity of developing this method at their experimental farm.

$\mathrm{He}$ is also indebted to his own Director, Professor M. L. 'т Hart, to the biometrician Mr. M. Keuls, and to Mr. D. S. MacLusky, B. Sc. (Agr.) of the Hannah Dairy Research Institute, Kirkhill, Ayr (Scotland), for correcting the manuscript.

\section{Bibliography}

Alexsson, Joel: Das Intensitätsproblem bei der animalischen Produktion. Ann. Landw. Hochschule Schwedens 11 (1943) 51-70.

BaLCH, C. C.: Factors affecting the utilization of food by dairy cows, Parts I and V. Brit. J. Nutrit. 4 (1950) $361-372$ and 6 (1952) 356-365.

Bosch, S. : Some results of an experiment with turning-in with different quantities of grass.

(Dutch with English summary). Versl. CILO over 1950, 68-71. 
Brown, Donothy : Methods of surveying and measuring vegetation. Commonw. Bur. Past. Field Crops Bull. 42 (1954) 135-139.

Drjkstra, N. D.: What has the State Agricultural Experimental Station at Hoorn contributed to research into the feeding value of roughage? Neth. J. Agr. Sci. 2 (1954) $273-297$.

Frankena, H. J. with M. P. Both : Some remarks on grassland plot technique. (Dutch) Versl. Lbk. Onderz. 45 (1939) 427-437.

GreEn, J. O. : Herbage sampling errors and grazing trials. J. Brit. Grassl. Soc. 4 (1949) $11-16$.

Holmes, W. and R. WAIte and co-workers: Studies in grazing management IV and V. J. Agr. Sci. 42 (1952) 304-321.

KLEY, F. K. VAN DER : Grazing behaviour in relation to feed intake by rotationally grazed monozygotic dairy cattle twins in the Netherlands. (Dutch with English summary). Landbouwk. Tijdschr. 67 (1955).

I. (with H. van Der Ploeg), Grazing behaviour : 609-619.

II. Grass consumption in relation to grazing management : 620-628.

- a : A critical review of methods for measuring herbage consumption by grazing cattle and sheep. (Dutch with English summary). Landbouwdocumentatie 12 (1956) 169-186.

- - b : Some alterations in mineral composition of grass and clover available and consumed during rotational grazing in the Netherlands. (Dutch with English summary). Landbouwk. Tijdschr. 68 (1956) in the press.

MenNer, A.: Untersuchungen über Ertrag und Verzehr an Weidefutter und Milchleistung. Z. Züchtungskunde 22 (1950) 32-44.

\title{
THE MICRO-ORGANISMS DECOMPOSING PECTIC SUB- STANCES IN THE DEW RETTING PROCESS OF FLAX ${ }^{1}$
}

\author{
K. T. WIERINGA
}

Laboratory of Microbiology, Agricultural University, Wageningen

In contrast to the water retting of flax, the dew retting is a process in which the pectic substances are broken down aerobically. The flax straw is spread out in thin layers in the field, which is mostly of grass or stubble, and left open to the influence of climatic conditions. If necessary it is turned over once or twice. The flax straw is thus exposed to the attack of aerobic microbes, and the process is dependent on the moisture and temperature conditions resulting from the weather during the retting period. Under these circumstances no control of the process is possible. This is another point of contrast, especially with the warm water retting process, which can be controlled to a considerable extent.

Whereas the organisms causing warm water retting are largely known, our knowledge of those active in dew retting is poor.

In earlier publications (BeHRENs, $1902 \mathrm{a}$, RuschManN, 1923) Rhizopus nigricans Ehrenb and Rhizopus hiemalis Wehmer, and Cladosporium herbarum (Link) Fr. were estimated as being the most important fungi in dew-retting. BeHrens (1902 b), criticising HaumanN (1902) stated that bacteria are of little significance in dew retting. RuschmanN considered Cladosporium herbarum to be the most important retting fungus : it suppressed the growth of Rhizopus and Mucor species and the presence of other fungi, yeasts or bacteria seemed

1) Received for publication in January 9, 1956. 